\title{
Book Review: \\ Iñiguez de Heredia, M. \& Wai, Z. (Eds.). (2018). Recentering Africa in International Relations. NY: Palgrave Macmillan, 349 p.
}

\author{
C.A. Amuhaya \\ People's Friendship University of Russia (RUDN University), \\ Moscow, Russian Federation
}

\begin{abstract}
"Recentering Africa in International Relations" draws a reader into a new understanding of the contemporary Africa. The book is formed as a collection of essays with different research focus but one shared research question - whether Africa is included or excluded from world politics? "Does the persistent peripheralization of Africa owe to the fact that it has very little to contribute to global politics or whether it is because the dominant trends, and modalities of the discipline of international relations (IR), as well as the ideological concerns of its major practitioners, are such that they consistently obfuscate and write over the very important ways the continent constitutes, and is constitutive, of world politics and global power". The authors are examining rather complicated relationship between Africa and the power-knowledge IR regimes, and ask how the dominant modalities and the discourses of the discipline, which is still Western-based by its origins, construct Africa as an object of knowledge and what the implications of these constructions mean for the continent. The strong point is the vast majority of issues covered by the contributors - from anthropology with focus on the "independence generation" of African leaders to the current agenda issues, like armed conflicts, state failures, local practices and regional ideas.
\end{abstract}

The starting point of the book that unifies in some way all authors' approaches is that "Africa is a worldhistorical region that has, at least in the context of modernity, always been an essential / integral part of the global system and remains a major constitutive site for world politics and global power". The novelty of the book could be described in its fair, rather transparent and not simplified character. The authors rightly suggest that the issue of Africa's position in global politics cannot be reduced to discourses of inclusion / exclusion. This way of thinking is too simple, as the idea of the continent's exclusion is in fact a myth, for it has always been a major constitutive part of capitalist modernity. Critical scholarship about Africa has many times argued that the problem of Africa is not its exclusion, but in fact the ways in which it has been inserted in world politics and its web of trade, institutions, and knowledge production mechanisms. In this logic most authors seem to be inclined in some way to the neo-Liberal or even Constructivist approaches, assuming that the whole analyses about the role of Africa in IR should be about how it is inserted in this system and what this has meant for its people. On the other hand, when it comes to Africa, the existing theoretical and practical approaches look too simple and straight forward; the whole issue should be approached with a little bit of caution. The authors indeed are demonstrating in the various chapters, that Africa has had, is having and will have a place in international relations system, once it is able to be identified not through the eyes of the West but Africans themselves.

A strong advantage of the book is the attempt to provide examples for exploring Africa's contribution to the international relations in all ways and forms. For instance, African philosophers, like Anton Wilhelm Amo, who made contributions to empiricists' epistemologies. Africa is full of world-historical political figures, like Haile Selassie, the Emperor of Ethiopia, who gave birth in his famous speech in 1936 to the concepts of "collective security" and "international morality" that became truly dominant.

Within this context, the book is as refreshing as authors employ metaphors not only showing the Africa's place in international relations, but also trying to understand the reasons of the continent's marginalization, by exploring the issues of colonial past, colonial education, situation with the so-called failed states from Eurocentric view point, and others. But even more significantly the authors try to address 
ways of fixing these issues. They discuss the assumption that salvation lays with western interventions which are Eurocentric invention of Africa and they offer a paradigm shift from idea of Africa to the African idea [Iñiguez de Heredia, Wai 2018: 284] as one of the many solutions.

The vast number of concluding remarks could be summarized in one short thesis - Africa has a place in international relations and it has contributed hugely to the field, in spite of the fact that Africa is still represented and largely analyzed through the prism of failure and past challenges. "Despite the fact that the continent has been and continues to be an essential part of the making of the modern world, its relevance to IR is not seen as self-evident, and despite years of critical intervention or even attempts to illustrate otherwise, the dominant renditions of IR and world politics still treats Africa, its peoples, cultures, and histories with scant regard; negating its contributions which are either written over or appropriated unacknowledged, while its knowledge, especially that produced by scholars based on the continent, is largely ignored". The book tries to get read of stereotypes and traditional tags about Africa, but the authors forming some big idea about the interlink between the continent and the globe are far from sharing all the assumptions. The approaches, for instance, to the colonial past, colonial library and others are different. This greatly contributes to the debate, and largely enhances it. For Wai and Mudimbe, the most fundamental task is to know Africa, its history and present. For Amina Mama, the answer is necessarily complex because it takes particular understandings to produce a counter-weight to the unethical ways in which Africa is generally studied. What Mama argues is that studying Africa can be ethical if it is self-reflective of the reproduction of tropes and forms of exploitation and also if it works towards social justice. In different formats proposed by the authors, recentering Africa means recentering IR, showing in the process that they are co-constitutive.

\title{
References / Библиографический список
}

Iñiguez de Heredia, M. \& Wai, Z. (Eds.). (2018). Recentering Africa in International Relations. NY: Palgrave Macmillan.

Received: 15.01 .2019

For citations: Amuhaya, C.A. (2019). Book Review: Iñiguez de Heredia, M. \& Wai, Z. (Eds.). (2018). Recentering Africa in International Relations. NY: Palgrave Macmillan, 349 p. Vestnik RUDN. International Relations, 19 (2), $327-328$. DOI: $10.22363 / 2313-0660-2019-19-2-327-328$.

About the author: Amuhaya Claire Auyma - PhD Student, Assistant of the Department of Theory and History of International Relations, Peoples' Friendship University of Russia (RUDN University) (e-mail: amukhaya-k@rudn.ru).

DOI: $10.22363 / 2313-0660-2019-19-2-327-328$

\section{Рецензия на монографию: Recentering Africa in International Relations / Ed. by M. Iñiguez de Heredia and Z. Wai. NY: Palgrave Macmillan, 2018. 349 p.}

\author{
К.А. Амухайя \\ Российский университет дружбы народов, Москва, Российская Федерация
}

Дата поступления статьи: 15.01.2019

Для цитирования: Амухайя К.А. Рецензия на монографию: Recentering Africa in International Relations / Ed. by M. Iñiguez de Heredia and Z. Wai. NY: Palgrave Macmillan, 2018. 349 р. // Вестник Российского университета дружбы народов. Серия: Международные отношения. 2019. Т. 19. № 2. С. 327-328. DOI: 10.22363/2313-0660-2019-19-2327-328.

Сведения об авторе: Амухайя Клэр Аюма - аспирант, ассистент кафедры теории и истории международных отношений Российского университета дружбы народов (e-mail: amukhaya-k@rudn.ru). 